В. Н. Чисников, доктор юридических наук, доцент, главный научный сотрудник, Государственный научно-исследовательский институт МВД Украинь, г. Киев

ORCID: https://orcid.org/0000-0003-2020-7298

\title{
КИЕВСКИЙ ПРОФЕССОР Н. А. ПЕТРОВ - ОДИН ИЗ ОСНОВАТЕЛЕЙ УКРАИНСКОЙ ШКОЛЫ СУДЕБНОЙ ФОТОГРАФИИ (к 145-летию со дня рождения и 80-летию со дня смерти)
}

Освещены жизненный путь и творческая деятельность одного из основоположников отечественной фотографии, пионера светописи, крупнейшего фотохудожника начала XX в., профессора Николая Александровича Петрова (1875-1940), который почти 40 лет работал в научных и учебных заведениях Киева, являясь одним из основателей украинской школы судебной фотографии.

Ключевые слова: Н. А. Петров; история фотографии; судебная фотография; светопись; Киевский кабинет научно-судебной экспертизы; Киевский политехнический институт.

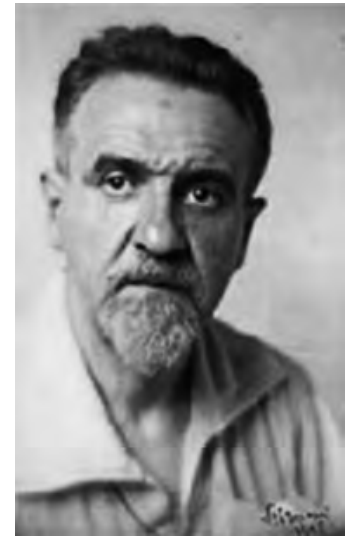

Н. А. Петров
В истории криминалистики нередко встречаются выдающиеся личности, которые по тем или иным причинам продолжительное время были незаслуженно забыты. К таким относится и профессор Николай Александрович Петров (1875-1940) - один из основоположников отечественной фотографии, пионер светописи, крупнейший фотохудожник начала XX в., который почти 40 лет работал в научных и учебных заведениях Киева, в том числе и в Кабинете научно-судебной экспертизы, являясь одним из основателей украинской школы судебной фотографии. В 2020 г. Николаю Александровичу исполнилось бы 145 лет со дня рождения и 80 лет со дня смерти.

Долгое время о Николае Петрове и его творчестве почти не вспоминали. И только в конце XX в. его имя стало встречаться в научных статьях, посвященных истории развития отечественной криминалистики. При этом упоминался Н. А. Петров, главным образом, как последователь «отца судебной фотографии» Е. Ф. Буринского и соратник профессора В. И. Фаворского, с которым они в конце 20-х гг. XX в. завершили цикл научно-исследовательских работ, посвященных озоброму.

Никаких биографических сведений ни в одной научной работе об ученом-криминалисте тогда не сообщалось. И только благодаря статьям в

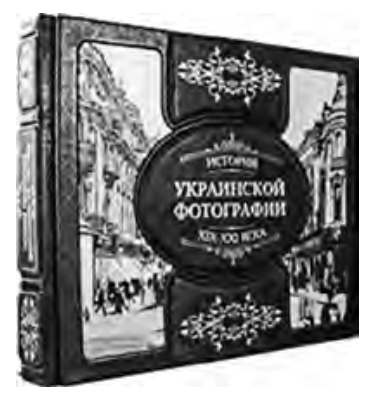

Интернете киевского исследователя А.И. Трачуна, впоследствии вошедшим в его капитальный труд «История украинской фотографии XIX-XXI века», появилась возможность ознакомиться с работами фотомастера (Trachun, 2014, s. 209). Жизненный путь и научная деятельность Петрова-криминалиста освещались также автором данной статьи (Chysnikov, 2013, s. 507-511).

Будущий фотоэнциклопедист Николай Александрович Петров родился 19 (6) сентября 1875 г. в г. Ельце Орловской губернии в купеческой семье потомственного почетного гражданина Александра Александровича Петрова. Род Петровых известен в Ельце с XVI в. Петровы - купцы первой гильдии, торговали зерном и мукой собственного производства, имели две мельницы, на которых трудились около сотни работников. Владели салотопенным и мыловаренным заводами, где производством заведовал мастер, проходящий практику в Германии. Петровские товары пользовались спросом не только в центральной России, но и во всей Прибалтике. Однако главным делом жизни четырех поколений этой семьи стало строительство в Ельце величественного Вознесенского собора. Горожане окрестили его малым Исаакием, сравнивая с грандиозным Исаакиевским собором в Санкт-Петербурге.

В семье А. А. Петрова воспитывалось двое сыновей. Николай, который был младше своего брата на 14 лет, в 1894 г. окончил Воронежскую 


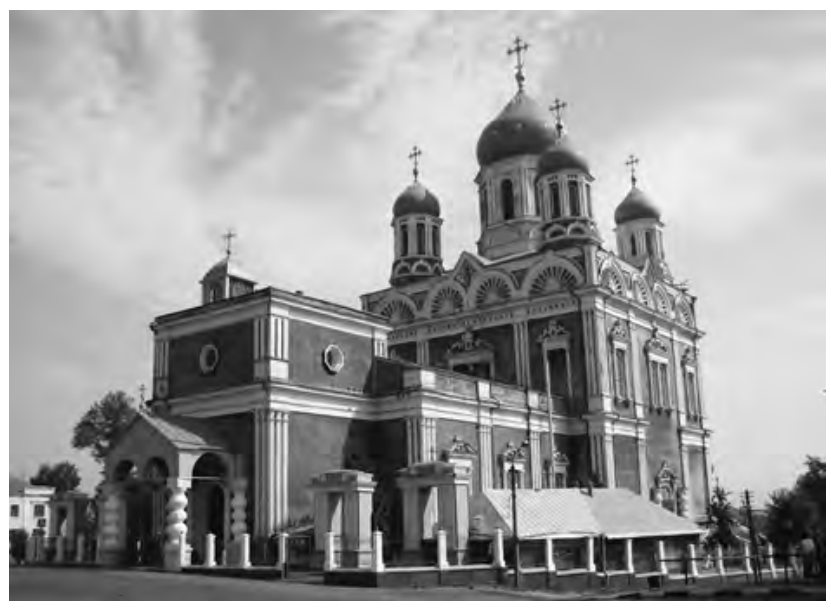

Вознесенский собор, Елец

гимназию. После смерти отца, случившейся в этом же году, управление большим наследством легло на плечи старшего брата Александра (в свое время отец, заботясь о продолжении семейного дела, забрал его из Московского училища живописи, ваяния и зодчества). Материально поддерживаемый старшим братом, Николай поступил на сельскохозяйственное отделение Рижского политехнического института, которое окончил в 1900 г., получив специальность агронома.

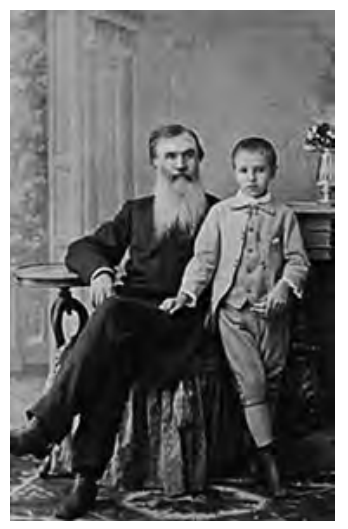

Коля Петров с отцом, 1883 г.
Следует сказать, что еще 12-летним гимназистом Николай заинтересовался любительской фотографией, которая в 1880-е гг. в России только переживала становление. Отец одобрял и всячески поощрял увлечение младшего сына. Больше всего Николаю нравилось снимать портреты, пейзажи, жанровые сцены. Любимое занятие он не оставил и в институте, достигнув заметных успехов (Tikhenko, 1948; Tikhenko, \& Lisichenko, 1967; Sapun, \& Segai, 1967). Свою первую награду - золотой жетон студент-второкурсник Николай Петров получил в 1896 г. на фотографической выставке в Риге, что, несомненно, подтолкнуло его продолжать изучение фотодела и заниматься научной деятельностью.

По окончании института Н. А. Петров два года провел в Карлсруэ (Германия), где совершенствовал свои познания в области химии, бактериологии, а также фотографии под руководством профессора Ф. Шмидта. Знание французского, немецкого, английского языков, полученное еще в Ельце при домашнем воспитании, ему очень пригодилось. Годы, проведенные в Риге и в Германии, привили Н. А. Петрову интерес к западноевро- пейской культуре и способствовали его становлению как ученого и фотохудожника.

Вернувшись из Германии, Николай Александрович женился и в 1903 г. переехал на постоянное место жительства в Киев, где сначала был определен вольнослушателем на кафедре ботаники Политехнического института (КПИ), так как занимался проблемами физиологии растений. В янваpe 1905 г. получил должность внештатного лаборанта, хотя и не предполагавшую денежного содержания, но с предоставле-

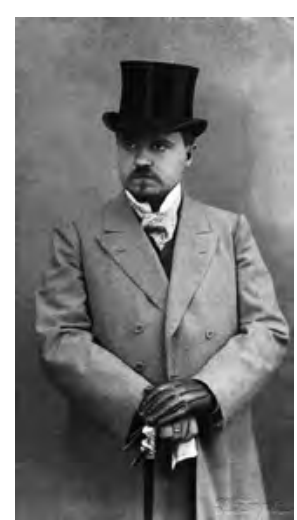

Н. А. Петров, 1902 г. нием всех прав и преимуществ государственной службы, за исключением права на пенсию. Он также начал читать лекции в КПИ и первым в России вести практические занятия по фотографии в высших учебных заведениях. Развивая это направление, Н. А. Петров разработал специализированные курсы (история фотографии, практическая фотография, техническая фотография), которые вскоре стал преподавать в нескольких средних и высших учебных заведениях Киева.

Со временем молодой ученый, обобщив опыт работы по созданию специальной фотографической лаборатории при механических мастерских КПИ, ввел в учебную программу новый курс «Фотокинолаборатория». В этой фотографической лаборатории, вскоре признанной одной из лучших в стране, позднее не только получали практические навыки студенты, но и проводилась значительная научно-исследовательская работа. Результатом стала разработка используемых при проведении судебных экспертиз новых методов исследования вещественных доказательств путем их фотографирования в инфракрасных, ультрафиолетовых и рентгеновских лучах, а также технологии прочтения выцветших, стертых или вытравленных надписей и др. Таким образом, благодаря Николаю Александровичу более чем на два десятилетия Киевский политехнический институт стал центром развития фотографических технологий в Украине.

В 1908 г. умирает жена Петрова - Анна Владимировна. Второй раз Николай Александрович женится на бывшей воспитательнице племянников Надежде Дмитриевне Козловой, которую знал совсем юной девушкой еще в Ельце. Она любила мужа и жизнь свою посвятила ему. Детей у Петрова, к большому его сожалению, не было ни в первом, ни во втором браке.

Надежда Дмитриевна, чтобы помочь семье материально, давала на дому платные обеды молодым ученым и педагогам, которые часто соби- 
рались у них на Мариинско-Благовещенской, 74 (ныне Саксаганского). По вечерам квартира Петровых, следует заметить, расположенная по улице, на которой в те годы проживали лучшие представители киевской интеллигенции, становилась центром жарких дискуссий по различным вопросам естествознания.

Начавшийся в Киеве расцвет творчества фотохудожника совпал с активной исследовательской работой в области общей, художественной, прикладной и научной фотографии. Н. А. Петров первым в России предложил метод вирирования бромосеребряных отпечатков в красно-коричневый тон, метод получения диапозитивов, исправления жестких негативов, разработал ряд методов позитивной печати, способ получения дуотоновых отпечатков, а также многоцветных комбинированных фотографий, выполняемых с помощью озоброма. Еще в 1903 г. мастер выступил с докладом «Озотипия», где представил фотоработы, выполненные указанным способом. Вопросы теории были освещены в его публикациях: «Озобром» (1910 г.), «Опыты применения озоброма к гуммиарабиковому способу» и «Масляный способ в художественной фотографии» (1911г.), «Упрощенный бромо-масляный способ» (1913 г.), «Исторический очерк развития и опыт классификации фотографических способов печати на солях хромовой кислоты» (1915 г.).

Занимался фотохудожник и вопросами фотохимии, теории и практики фотопроцессов. По сути, Петров стал одним из пионеров теории художественной фотографии, осветив достижения в ряде публикаций: «Может ли фотография служить методом искусства» и «Место светописи среди других методов изобразительного искусства, ее преимущества и область применения» (1912 г.), «Значение новейших способов печати для художественной светописи» (1913 г.).

В 1912 г. в Германии вышла в свет книга Н. А. Петрова «Художественная фотография в России», а в 1913 г. в Англии - «Пикториальная фотография в России». Всего за рубежом, по подсчетам исследователей, Николай Александрович опубликовал на разных европейских языках более 40 научных работ.

В России большинство статей Н. А. Петрова издано в московском журнале «Вестник фотографии», где он руководил художественным отделом и до 1915 г. состоял членом редколлегии.

Печатался Николай Александрович и в журналах «Светопись» (1907 г.), немецком «Фотографическом искусстве» (1912 г.), «Известиях киевской рентгеновской комиссии» и др.

В начале XX в. Н. А. Петров был инициатором, организатором и участником ряда отече- ственных и зарубежных фотовыставок: в Петербурге (1905 г.), Москве (1908 г.), Саратове (1908 г.), Казани (1909 г.), Дрездене (1909 г.), Будапеште (1910 г.), Киеве (1911 г.), Антверпене (1912 г.), Иркутске(1912 г.), Лондоне (1913г.), Воронеже(1914г.), Симферополе (1914г.), Одессе (1915 и 1917 г.), Гамбурге (1916 г.) и др.

Посетители фотовыставок были в восторге от киевского фотомастера, о чем неоднократно сообщалось в средствах массовой информации.

Николай Александрович был выдающимся деятелем отечественного фотодвижения. Он подготовил в Киеве Второй съезд русских деятелей фотографического дела (1908 г.), был автором

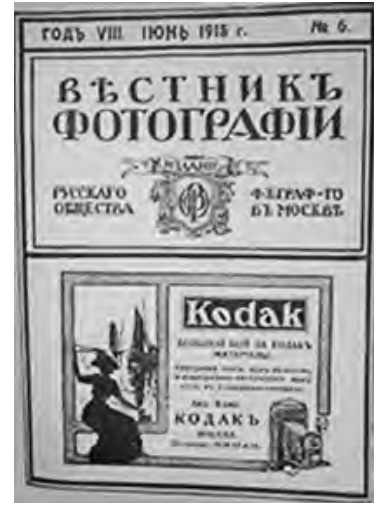

Обложка журнала «Вестник фотографии», июнь 1915 г.
Положения о Втором съезде, в котором нашло отражение создание системы фотообразования в России. В 1906-1912 гг. Николай Петров возглавлял киевское общество фотографов-любителей «Дагер», члены которого занимались теоретическими и практическими разработками в сфере фотографии, использованием ее в научных целях, съемкой исторических памятников Украины, активно сотрудничали с другими фотообъединениями. Больше десяти лет (1906-1917 гг.) Николай Александрович руководил фотоотделом киевского отделения «Императорского русского технического общества».

За заслуги в области фотоискусства Н. А. Петров был избран почетным членом ряда отечественных фотообъединений: Русского фотографического общества (Санкт-Петербург), Рижского, Московского, Воронежского, Иркутского, Одесского, а также зарубежных обществ (в частности Гамбургского), был членом-корреспондентом Дрезденского общества фотографии.

Несмотря на более чем скромную должность лаборанта Киевского политехнического института, Николай Александрович дослужился до чина коллежского советника (1913г.), что согласно российскому «Табелю о рангах» соответствовало воинскому званию полковника и давало право на личное дворянство. В 1914 г. за усердную и образцовую службу ему был пожалован орден Святого Станислава.

В 1916 г. Н. А. Петрова как одного из ведущих специалистов в области фотографии прикомандировали к Кабинету научно-судебной экспертизы при прокуроре Киевской судебной палаты (к сожалению, пока не удалось найти каких-либо сведений о его деятельности в этот период). 
В октябре 1918 г. Николая Александровича назначают помощником управляющего указанного кабинета. Как отмечают исследователи, после гражданской войны усилиями выдающихся деятелей того времени (В. И. Фаворского, Н. А. Петрова, Н. Н. Туфанова, В. А. Франковского и

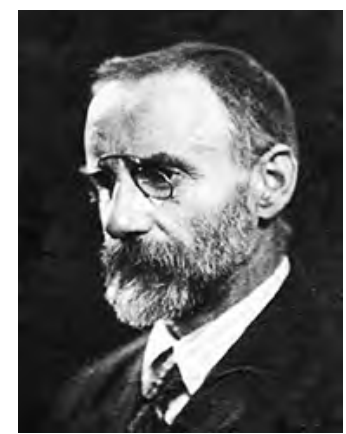

В. И. Фаворский принятого на должность фототехника В. Л. Павлова) кабинет удалось восстановить и возобновить производство судебных экспертиз: дактилоскопических, трасологических, судебно-химических, по исследованию документов (Belkin, 1999, s. 92-93).

Возглавляя секцию судебной фотографии, Н. А. Петров специализировался, как указывалось в докладной записке В. И. Фаворского от 5 марта 1923 г., на проведении исследований по научной фотографии, дактилоскопии и пороскопии (Tcentralnyi gosudarstvennyi arkhiv. F. 8. Op. 1. D. 1309. L. d. 49).

В 1924 г. Н. А. Петрову было присвоено ученое звание профессора. После реорганизации в 1925 г. Киевского областного кабинета научно-судебных экспертиз в институт (ныне Киевский научно-исследовательский институт судебных экспертиз КНИИСЭ) Н. А. Петров назначен начальником отдела фотографических исследований. Занимал он эту должность до 1934 г. Наряду с производством экспертиз по заданиям следственных и судебных органов профессор активно занимался научно-исследовательской работой. В частности, в конце 1920-х гг. совместно с В. И. Фаворским завершил цикл трудов по судебной фотографии, усовершенствовав метод озобромного усиления контрастов, разработанный Е. Ф. Буринским. Применение данного метода позволяло читать выцветшие, вытравленные, стертые или по другим причинам превращенные в невидимые глазу подписи. О результатах этих исследований В. И. Фаворский объявил на радиоконференции в Одессе (1930 г.); опубликованы они и на страницах одного из научных журналов (Favorskyi, 1934, s. 78-82).

Под руководством профессора Петрова также были выполнены работы по созданию новых физических методов исследования вещественных доказательств в инфракрасных, ультрафиолетовых и рентгеновских лучах. Таким образом, профессора Н. А. Петрова наряду с В. И. Фаворским по праву считают основателем украинской школы судебной фотографии.

Почти 30 лет жизни Н. А. Петров отдал педагогической работе, являясь одним из ведущих педагогов в области фотографии в Киеве. Он первым в Украине начал читать «Практическую фотографию» в высшей школе, преподавал в Киевском политехническом институте (1906-1921 гг.), фототехникуме (1923-1924 гг.), Фотографическом институте (1924-1936 гг.), Художественно-промышленном училище (1926 г.), Кинофототехникуме (с 1930 г.), Государственном институте кинематографии (1930-1936 гг.) и др. В этих учебных заведениях профессор читал, в частности, следующие дисциплины: «Практическая фотография», «Энциклопедия фотографии», «История художественной фотографии», «История фотографии», «Фотокинолаборатория».

За годы советской власти Н. А. Петров почти не печатал статей по теории фотографии, тем не менее идеологический прессинг коснулся и его. В конце 1920-х гг. он был обвинен в увлечении салонной фотографией, «фотоэстетизме», формализме, недостаточной борьбе с западными течениями в фотоискусстве. Так, в 1928 г. некий Леонид Волков-Ланнит раскритиковал эстетические взгляды фотохудожника, а в 1930 г. в «Киногазете» появилась статья И. Цвилого «Оппортунизм в киевском киноинституте». В ней утверждалось, что Николай Петров не отвечает требованиям студентов. Автора статьи, видимо, оскорбила «идеологическая незрелость» профессора, который одну из своих статей подписал: «Преподаватель фотографии Политехнического института Императора Александра II Н. Петров». Видимо, поминание монаршего имени дало основание критику причислить профессора к числу «оппортунистов», хотя годом ранее ректор художественного института на страницах этой же газеты называл профессора Н. А. Петрова выдающимся специалистом.

В 1934 г. в газете «Вісті ВУЦВК»-центральном печатном органе украинского правительства была помещена статья-фельетон «Діла і дні» професора Фаворського», в которой, характеризуя научный потенциал института судебных экспертиз, автор-аноним сообщал, что из 30 сотрудников института только его директор Головченко является членом партии, а остальные - бывшие помещики, судебные следователи, судьи, дети попов и полковников. О профессоре Н. А. Петрове

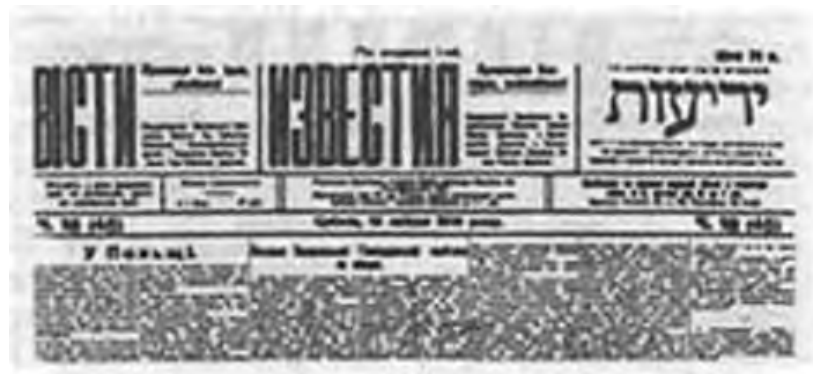

-Biern BYUBK. 
он с нескрываемой иронией писал: «зав. секції фотографічних досліджень Петров - колишній коннозаводчик і миловар, після революції він почув потяг до «наукової» роботи». В конце статьи «доброжелатель» призывал: «Треба, нарешті, очистити інститут від кубла шкідників, що засіли в ньому» («Dila i dni», 1934, s. 4).

К счастью, «великий террор» 30-х гг. профессора миновал и, несмотря на кляузы недоброжелателей, Николай Александрович продолжал заниматься педагогической, научной и общественной деятельностью. Под его редакцией была издана книга Г. Н. Поляка «Краткая фотоэнциклопедия. Словарь-справочник по всем вопросам фотографии и фототехники» (Киев, 1936 г.). В том же году он организовал в Киеве фотовыставку своих работ. Заметим, что такие фотовыставки в столице Украины фотомастер организовывал в 1922 и 1928 гг.

В 1936 г. известного фотографа настиг инсульт. Его глубоко травмировали усиливающиеся репрессии в стране, преследование семьи старшего брата Александра. Последние годы жизни Николай Александрович тяжело болел, был прикован к постели. Умер он 9 апреля 1940 г. на 65 году жизни, похоронен в Киеве.

Во время Великой Отечественной войны его жене с большими трудностями удалось выбраться из оккупированного немцами Киева и добраться до Москвы. С собой она привезла коллекцию мужа, насчитывавшую более чем 100 фотографий мастера, сохранив ее для потомков.

\section{References}

Belkin, R. S. (1999). Istoriia otechestvennoi kriminalistiki. M.: Norma. 496 s. [in Russian].

Chysnikov, V. M. (2013). Petrov Nykolai Aleksandrovych (1875-1940). Verbenskyi, M. H., Hyrko, S. I., Protsenko, T. O., Chysnikov, V. M., Pluhatar, T. A., Nikitina, I. E., \& Laptiev, S. H., Kryminalistychni reiestratsiino-dovidkovi y sudovo-ekspertni ustanovy Ministerstva vnutrishnikh sprav ta Ministerstva yustytsii Rosiiskoi imperii (1889-1917 rr.): u 2-kh kn. Kn. 2. Kyiv; Kharkiv: DNDI MVS Ukrainy. S. 507-511 [in Ukrainian].

«Dila I dni» profesora Favorskoho. (1934, 4 sich.). Visti VUTsVK, 4 (3991), s. 4 [in Ukrainian].

Favorskyi, V. (1934). Ozobrom u pozytyvnomu protsesi. Foto - sotsbudivnytstvu, 3/4, 78-82 [in Ukrainian].

Sapun, A. P., \& Segai, M. Ia. (1967). 50 let deiatelnosti Kievskogo nauchno-issledovatelskogo instituta sudebnoi ekspertizy. Kriminalistika i sudebnaia ekspertiza, 4, 37 [in Russian].

Tcentralnyi gosudarstvennyi arkhiv vysshikh organov vlasti i upravleniia Ukrainy (TcGAVO Ukrainy). F. 8. Op. 1. D. 1309. L. d. 49 [in Russian].

Tikhenko, S. I. (1948). Razvitie sovetskoi kriminalistiki na Ukraine. Kriminalistika i nauchno-sudebnaia ekspertiza, 2 , 13 [in Russian].

Tikhenko, S. I., \& Lisichenko, V. K. (1967). Razvitie kriminalistiki v Ukrainskoi SSR za 50 let Sovetskoi vlasti. Kriminalistika i nauchno-sudebnaia ekspertiza, 4, 9 [in Russian].

Trachun, A. I. (2014). Istoriia ukrainskoi fotografii XIX-XXI veka. Kiev: Baltiia-Druk. 255, [1] s. [in Russian].

\section{Список использованных источников}

Белкин, Р. С. (1999). История отечественной криминалистики. М.: Норма. 496 с.

Чисніков, В. М. (2013). Петров Николай Александрович (1875-1940). Вербенський, М. Г., Гирько, С. І., Проценко, Т. О., Чисніков, В. М., Плугатар, Т. А., Нікітіна, І. Е., \& Лаптєв, С. Г., Криміналістичні реєстраційно-довідкові й судово-експертні установи Міністерства внутрішніх справ та Міністерства юстиції Російської імперії (1889-1917 рр.): у 2-х кн. Кн. 2. Київ; Харків: ДНДІ МВС України. С. 507-511.

«Діла і дні» професора Фаворського. (1934, 4 січ.). Вісті ВУЦВК, 4 (3991), с. 4.

Фаворський, В. (1934). Озобром у позитивному процесі. Фото - соибудівництву, 3/4, 78-82.

Сапун, А. П., \& Сегай, М. Я. (1967). 50 лет деятельности Киевского научно-исследовательского института судебной экспертизы. Криминалистика и судебная экспертиза, 4, 37.

Центральный государственный архив высших органов власти и управления Украины (ЦГАВО Украины). Ф. 8. Оп. 1. Д. 1309. Л. д. 49.

Тихенко, С. И. (1948). Развитие советской криминалистики на Украине. Криминалистика и научно-судебная экспертиза, 2, 13.

Тихенко, С. И., \& Лисиченко, В. К. (1967). Развитие криминалистики в Украинской ССР за 50 лет Советской власти. Криминалистика и научно-судебная экспертиза, 4, 9.

Трачун, А. И. (2014). История украинской фотографии ХІХ-ХХІ века. Киев: Балтія-Друк. 255, [1] с. 
V. Chisnikov, DSc (Law), Associate Professor,

Chief Researcher,

State Research Institute MIA of Ukraine,

Kiev, Ukraine

ORCID: https://orcid.org/0000-0003-2020-7298

\section{KIEV PROFESSOR N. A. PETROV - ONE OF THE FOUNDERS OF THE UKRAINIAN SCHOOL OF FORENSIC PHOTOGRAPHY (to the 145th anniversary of Petrov's birthday and 80th anniversary of his death)}

This article covers the life path and creative activity of one of the founders of national photography, the pioneer of photography, the largest photographer of the early 20th century, Professor Nikolai Petrov (1875-1940), who worked for almost 40 years in scientific and educational institutions of Kiev, being one of the founders of the Ukrainian school forensic photography.

Keywords: N. Petrov; history of photography; forensic photography; light painting; Kiev office of scientific and forensic expertise; Kiev Polytechnic Institute.

В. М. Чисніков, доктор юридичних наук, дочент, головний науковий співробітник,

Державний науково-достідний інститут МВС України, м. Київ

ORCID: https://orcid.org/0000-0003-2020-7298

\section{КИЇВСЬКИЙ ПРОФЕСОР М. О. ПЕТРОВ - ОДИН ІЗ ЗАСНОВНИКІВ УКРАЇНСЬКОЇ ШКОЛИ СУДОВОЇ ФОТОГРАФІї (до 145-річчя від дня народження і 80-річчя від дня смерті)}

\footnotetext{
Висвітлено життєвий шлях і творчу діяльність одного з основоположників вітчизняної фотографії, піонера світлопису, найвизначнішого фотохудожника початку XX ст., професора Миколи Олександровича Петрова (1875-1940), який майже 40 років працював у наукових і навчальних закладах Києва, будучи одним із засновників української школи судової фотографії.

Ключові слова: М. О. Петров; історія фотографії; судова фотографія; світлопис; Київський кабінет науково-судової експертизи; Київський політехнічний інститут.
} 